$\mathrm{A} \mathrm{J}_{\mathrm{ats}} \mathrm{H}$

Received : 26.12.2017

Revised : 15.05 .2018

Accepted : 28.05.2018

Members of the Research Forum

Associated Authors:

${ }^{1}$ Department of Horticulture, Tirhut

College of Agriculture, Dholi

(Bihar) India
Author for correspondence : S.P. Singh

Department of Horticulture, Tirhut

College of Agriculture, Dholi

(Bihar) India

Email : spicestcadholi@yahoo.com
THEASIAN JOURNALOF HORTICULTURE

Volume 13 | Issue $1 \mid$ June, 2018 | 32-35

Visit us -www.researchjournal.co.in

\title{
Genetic variability in nigella (Nigella sativa L.)
}

\section{S.P. Singh and S.K. Singh ${ }^{1}$}

ABSTRACT : Analysis of variability carried out for ten characters in sixteen diverse genotypes of nigella (Nigella sativa L.) revealed high genotypic and phenotypic co-efficient of variations for secondary branches per plant, number of grains per fruit, number of fruits per plant, length of fruit $(\mathrm{cm})$ and width of fruit $(\mathrm{cm})$. Heritability estimates were high for number of grains per fruit (0.86), number of fruit per plant (0.78), length of fruit (0.64), days to maturity (0.59), number of secondary branches per plant $(0.56)$ and yield per plant $(0.47)$. Higher genetic advance as percentage of mean was recorded for number of grains per fruit $(46.11 \%)$, number of secondary branches per plant $(43.99 \%)$, number of fruits per plant $(39.65 \%)$, yield per plant $(24.49 \%)$, length of fruit $(24.12 \%)$ and indicating additive gene effect. Quantitative traits like days to maturity, number of secondary branches per plant, number of grains per fruit and number of grains per fruit exhibited wide range of variability (134.33-143.00) maximum genotypic co-efficient of variability (29.53), maximum phenotypic co-efficient of variability (22.18), broad sense heritability (0.86) and gene gain (46.11).

KEY WORDS : Nigella, Genetic advance heritability, Variability

HOW TO CITE THIS ARTICLE : Singh, S.P. and Singh, S.K. (2018). Genetic variability in nigella (Nigella sativa L.). Asian J. Hort., 13(1) : 32-35, DOI : 10.15740/HAS/TAJH/13.1/32-35. 